\title{
NATALIE ZEMON DAVIS KOBIETY NA MARGINESACH. TRZY SIEDEMNASTOWIECZNE ŻYCIORYSY [Wydawnictwo Naukowe PWN, Warszawa 2012, s. 392.]
}

Kobiety na marginesach. Trzy siedemnastowieczne życiorysy, to książka znanej amerykańskiej historyk - Natalie Zemon Davis. Jest to publikacja traktująca w szerszym kontekście o historii społecznej Europy siedemnastego wieku, a w szczególności o historii społecznej kobiet tego okresu. Książka, jak na publikację naukową przystaje, posiada imponujący zasób źródłowy, a nadto rozpoczyna się niezwykle i intrygująco. Dzieło otwiera kilkustronicowy „Prolog”, który jest wyobrażeniem autorki reakcji bohaterek książki na jej treść. W wyimaginowanej rozmowie Glikl bas Juda Lejb, Marie de l'Incarnation i Maria Sibylla Merian, tytułowe kobiety na marginesie, stawiają poniekąd pytania, które mógłby zadać także czytelnik o to dlaczego te trzy historie autorka postanowiła opowiedzieć. Marginalność, którą bada i do której odnosi się Davis wynika z tego, że bohaterki jej książki byly kobietami, żyjącymi w określonych miejscach i określonym czasie.

Każdej ze swoich bohaterek Natalie Zemon Davis poświęciła osobny rozdział. Czytelnik poznaje w pierwszej kolejności urodzoną w Hamburgu, pod koniec pierwszej połowy XVII wieku, Żydówkę - Glikl, córkę Judy Lejba. Była ona kobietą przedsiębiorczą, cieszącą się potomstwem ze swym pierwszym mężem Chaimem, pomnażającą rodzinny majątek także po jego śmierci. Podstawowym źródłem wykorzystanym przez Davis do badania jej życia jest autobiografia-pamiętnik spisana i pozostawiona przez nią dla jej dzieci. Wspomnienia oraz opowieści zebrane przez Glikl zostały umieszczone w kilku księgach, których treść oraz kształt były od początku zdefiniowane przez samą autorkę. Córka Judy Lejba świadomie budowała narrację w swoich zapiskach, niekiedy powracając do już spisanych części, aby nanieść poprawki. 
Drugą część publikacji Davis poświęciła Marie Guyart, znanej współcześnie jako Święta Maria od Wcielenia. Urodzona w 1599 r. w Tours katoliczka, pochodziła ze skromnej rodziny. Dość szybko została wydana za mąż, urodziła syna, a następnie została wdową, co umożliwiło realizację skrywanego i prawdziwego pragnienia jej życia - oddania się Bogu. Porzuciwszy fizycznie, lecz nie mentalnie swojego syna Claude’a Martina wstąpiła do zakonu. Z czasem pokonawszy wiele trudności, wyjechała do Nowej Francji w Kanadzie. Tam założyła klasztor urszulanek i pracowała z lokalną ludnością. Świadectwem działalności i życia Marie de l’Incarnation są zarówno jej własne zapiski o samej sobie, pozostawione książki pedagogiczne, jak i korespondencja z synem.

Rozdział trzeci traktuje o protestantce - Marii Sibylli Merian, urodzonej w 1647 roku we Frankfurcie nad Menem. Pochodziła z rodziny artystów i nie pozostawiła po sobie pamiętników. Jednak zachowały się przede wszystkim jej książki - była pierwszą kobietą entomologiem - a także, w niewielkim stopniu, korespondencja. Celem Marii Sibylli jako artystki i malarki było oddawanie piękna natury, którą badała, ale także odpowiedni zarobek. W kontekście życia duchowego Merian przez pewien czas należała do wspólnoty labadystów, którą ostatecznie porzuciła. Przynależność do sekty doprowadziła do rozpadu jej małżeństwa z Johannem Andreasem Graffem. Największym osiągnięciem Marii Sibylli była, biorąc także pod uwagę jej płeć, podróż zamorska do Surinamu, gdzie prowadziła badania i obserwacje nad lokalną fauną.

Lektura dzieła Natalie Zemon Davis nasuwa pewne refleksje dotyczące samej metodyki prowadzonych badań naukowych oraz wniosków, które można wysnuwać z dostępnych źródeł historycznych niezależnie od epoki.

Przede wszystkim badacz, który może korzystać ze źródeł stworzonych przez osobę, której historię bada - jak było w przypadku Davis - znajduje się w sytuacji pozornie idealnej. Z jednej strony są to własne przemyślenia konkretnego człowieka, a w przypadku pamiętników pisanych na własny użytek, zapiski być może niezmanipulowane przez wplyw środowiska. W istocie jednak posługiwanie się wyłącznie takim źródłem może okazać się pułapką badawczą, gdyż znaną i powszechną ludzką cechą jest chęć bycia widzianym w lepszym świetle, niż jest się w rzeczywistości. Z takim problemem Natalie Zemon Davis bez wątpienia spotkała się opowiadając historie dwóch pierwszych bohaterek swojej książki. Dość przywołać sytuację z nanoszeniem poprawek przez Glikl na wspomnieniach o kłótni małżonka. Narracja kobiety zebrana w siedmiu księgach, zaplanowanych już na początku trzydziestu lat pracy nad wspomnieniami, podlegała redakcji lub korekcie dokonanej przez córkę Judy Lejba. 
Dbałość o to, aby odpowiednie historie znajdowały się w odpowiednich miejscach może sugerować, że część zapisków uzyskiwała z czasem złagodzony kształt, a zatem nie w pełni odpowiadała stanowi, w jakim autorka znajdowała się podczas spisywania pamiętnika. Badanie źródel, które powstały po to, aby stworzyć pożądany obraz ich autora (w tym przypadki Glikl), jest z jednej strony wyzwaniem dla historyka, z drugiej jednak badacz już na początku pracy zna intencję, z uwagi na którą źródło może nie mówić prawdy.

Odpowiednią dozę krytycyzmu należy przyjąć także wobec źródeł, które informują o kimś innym niż sam autor tekstu, ale zostały stworzone przez osobę bliską. Przykładem są tutaj zapiski Claude’a, syna Marie de l'Incarnation, który sam stał się zakonnikiem. Badacz może postawić pytanie, czy notatki dziecka, które było odpychane przez matkę, dziecka nieznającego ojca, nadto dziecka porzuconego błagającego pod bramami klasztoru, aby oddano mu matkę, i które $\mathrm{z}$ tego powodu było wyśmiewane przez rówieśników, a następnie młodzieńca, któremu odebrano rentę z powodu decyzji Marii o wyjeździe do Kanady, mogą oddawać chociaż częściowo jej prawdziwe oblicze czy jego prawdziwe zdanie o niej. Nadto na ile istotna jest religia oraz umiejscowienie w czasie i przestrzeni takiej korespondencji? Wpływu okoliczności kulturowych i społecznych nie można nigdy lekceważyć. Nie bez znaczenia jest fakt, że Claude wybrał życie zakonnika; zarówno on, jak i jego matka byli zaangażowani w zinstytucjonalizowane życie religijne, a w związku z tym opisywali swe życia i postawy w odniesieniu do wyznawanej wiary i dyktowanych przez nią postaw i wartości.

Z podobnymi dylematami zmagają się także badacze innych epok, nawet odległych, takich jak starożytność. Przykładowo analizując listy starobabilońskie, należy mieć na uwadze sposób, w jaki były konstruowane, dostarczane oraz odczytywane; na każdym z etapów wymiany korespondencji poza nadawcą i adresatem, bezpośredni dostęp do treści wiadomości mieli także pośrednicy - skryba i goniec. Wniosek wspólny dla tych przykładów jest taki, że nawet jeśli istnieje możliwość badania życia konkretnej osoby na podstawie pozostawionych przez nią osobiście (lub niemal osobiście) źródeł, to należy brać pod uwagę także mogącą się pojawić chęć kształtowania swojego wizerunku, a niekiedy nawet uleganie pewnej propagandzie. Szczególnie istotna jest specyfika wierzeniowa i religijna, a także związane z nią uwikłanie w sferę symboliczną. Badacz, który zajmuje się epokami silnie nasyconymi symbolicznie i pochyla się nad problemami społecznymi musi mieć zawsze na uwadze to, w jaki sposób odtwarzać ówczesną rzeczywistość nie nakładając na nią jednocześnie doświadczeń współczesnych. 
W przypadku Glikl oraz Marii od Wcielenia podstawę źródłową stanowiły, jak już wskazano, nie tylko zapiski, które same po sobie i o sobie zostawily, ale także, w drugiej kolejności, relacje innych osób o nich. Musiały się one okazać bardzo pomocne i umożliwić należytą krytykę źródła, bowiem autorka w oparciu także o nie, raz po raz czyni w tekście uwagę, że któraś z bohaterek książki coś sama o sobie lub o czymś powiedziała czy napisała nieszczerze. Innym razem Natalie Zemon Davis bardzo błyskotliwie zauważa, że któraś z kobiet coś w swych zapiskach pominęła celowo. Przykładem jest tutaj Maria Sibylla Merian, która w swoim dziele dotyczącym fauny i flory Surinamu nie złożyła nikomu podziękowań, ani nikogo nie wyróżniła dedykacją, chociaż udzielono jej pożyczek, bez których podróż do Ameryki byłaby niemożliwa. Autorka Kobiet na marginesie odwołuje się do relacji innych osób o bohaterkach swojego dzieła, aby móc zrealizować najważniejszy i podstawowy cel, którym jest prawdziwe opisanie tytułowych kobiet, uwzględniające to kim i jakie były.

W przypadku rozdziału poświęconego Marii Sibylli Merian podstawą źródłową były przede wszystkim jej prace artystyczne, które wraz z upływem czasu opatrywała coraz bardziej ubogimi komentarzami, a nadto znane listy, które wysyłała do swoich przyjaciół i które oni do niej słali, a także dokumenty urzędowe dotyczące wniosku jej męża Johanna Andreasa Graffa o rozwód. Jak sama Natalie Zemon Davis wskazuje, obraz Merian, który zrekonstruowała nie jest uzupełniony przez relacje i opinie córek Marii Sibylli, bowiem autorka nie miała do takich dostępu. Bez wątpienia informacje o tym jak była postrzegana przez córki mogłyby być niezwykle interesujące. Szczególnie $\mathrm{z}$ uwagi na fakt, że młodsza z córek była razem z matką w Surinamie. Autorka Kobiet na marginesie czyni ważne uwagi na podstawie tych źródeł, którymi dysponowała. Przykładowo zwraca uwagę na to, że pierwsze publikacje Merian były opatrywane wierszami pochwalnymi na cześć Boga i jego dzieła, jednak z czasem, wraz z ewolucją życia duchowego, którą Maria Sibylla Merian bez wątpienia przechodzi, komentarze te zniknęły. Możliwość wyciągnięcia wniosków, o tym że wpływ na zmianę w duchowości artystki miał jej pobyt we wspólnocie labadystów wynika z obecności innych źródeł, z których Natalie Zemon Davis mogła skorzystać. Sposobność do uzupełniania rekonstruowanego obrazu, niezależnie od epoki, o inne źródła, niż zwykle badane, które dotyczą tego samego problemu jest oczywiście nie do przecenienia. Na uwagę zawsze zasługują źródła ikonograficzne, o ile są dostępne. Możliwość poddania ich analizie, daje badaczowi wgląd w zarówno w trendy i zwyczaje kulturowe oraz symboliczne obecne w danej epoce, jak i pozwala docenić kunszt autora.

Dla młodego badacza, który nadal kształtuje swój warsztat, pouczający jest dobór bohaterek książki, którego dokonała Davis. Wszystkie kobiety żyły, a przynajmniej 
urodzily się w sercu siedemnastowiecznej Europy, ale każda wyznawała inną religię. Dzięki temu, że książka traktuje o życiu Żydówki, katoliczki i protestantki możliwe jest stawianie pytań o to, w jaki sposób konkretna religia, w danym miejscu i czasie, determinowała życie ludzi, w szczególności kobiet. Glikl bas Juda Lejb mogła rozwijać zarówno talent do handlu, jak i pomnażać rodzinny majątek właśnie dlatego, że była Żydówką; od kobiet tego wyznania oczekiwano pracy i nie postrzegano jej jako coś gorszącego. W przypadku Marii Sibylli Merian ma miejsce nie tyle podążanie za wytycznymi obyczajów i religii, co przełamywanie pewnego wzorca. Artystka bez towarzystwa mężczyzny, jako osoba prywatna razem ze swoją młodszą córką udała się w zamorską podróż do Ameryki, chociaż w jej czasach o kobietach tak czyniących wygłaszano całkowicie negatywne opinie. Tym, co łączy każdą z trzech bohaterek jest także fakt, że pochodziły z tytułowego marginesu, ale margines ten należy chyba traktować jako pewien umowny konstrukt. Nie był to przecież prawdziwy margines społeczny - nawet o niezamożnej rodzinie, z której pochodziła Marie de l'Incarnation nie można powiedzieć, że była to najprostsza biedota francuska. $Z$ kolei Merian wywodziła się z rodu, w którym nie pierwsze pokolenie zajmowało się zarobkowo prezentowaniem natury, a artyści za swoje dzieła umieszczane w książkach mogli być wówczas hojnie wynagradzani. Z drugiej strony, spoglądając na dwory królewskie i ludzi, którzy rozgrywali w siedemnastym wieku europejską politykę, ich wpływy, bogactwo i możliwości, to rzeczywiście życie trzech nieznanych kobiet zaczyna być marginesem. Ów margines zależy jednak od tego, gdzie ustanowi się centrum, gdzie będzie się skupiać największą uwagę. Te wszystkie okoliczności Natalie Zemon Davis wykorzystała w sposób godny uznania; opisując historie wybranych przez siebie osób otworzyła metaforyczne okno na poznanie ówczesnych realiów w ogóle. Dzieło Davis jest przepełnione informacjami na temat siedemnastowiecznych zwyczajów oraz uwagami na temat życia codziennego. Dla uzupełnienia obrazu autorka opowiada także historie innych osób, które w jakiś sposób wpływały na bohaterki książki, albo na które one wpływały. Umiejętność budowania narracji w taki sposób, w jaki czyni to autorka, jest pożądana również przez historyków zajmujących się innymi epokami. Historia starożytna także zna przykłady kobiet, które w szerszym kontekście nie mogłyby same o sobie decydować, ale urodzone w pewnych uprzywilejowanych kręgach miały większy wpływ na swoje życie. Przykładem mogą być niektóre starobabilońskie kapłanki, znane jako naditu. Zwykle pochodzące z dobrze sytuowanych rodzin mogły nawet samodzielnie wynajmować części nieruchomości i nimi zarządzać, co było poza zasięgiem zwykłych kobiet. 
Wydanie Kobiet na marginesie zostało wzbogacone o różne obrazy, które odnoszą się do życia Glikl, Marie oraz Merian. Decyzja o ich zamieszczeniu, a także sam dobór reprodukcji zasługują na uwagę. Szczególnie jeśli chodzi o ostatnią z kobiet - nie pozostawiła po sobie zapisków traktujących o jej życiu, tak jak miało to miejsce u dwóch pozostałych bohaterek Davis. Umiejętne dobieranie obrazów i grafik wzbogaca tekst, uzupełniając wyobrażenia kształtowane przesz treść książki. Rozdział poświęcony Glikl został zaopatrzony w ikonografię odnoszącą się do życia Żydów; ukazano chociażby dzielnicę żydowską w Metzu w roku 1696, zachowanie żydowskich kobiet w związku ze świętami religijnymi czy przykłady pisma żydowskiego. Część książki dedykowaną życiu Marie de l'Incarnation wzbogacono o przedstawienia między innymi konwentu urszulanek czy porównanie pisma zakonnic i Indianek. W rozdziale, w którym autorka opisała historię Marii Sibylli również zamieszczono interesujące i piękne obrazy. Są to przede wszystkim miedzioryty wykonane ręką Merian ukazujące owady i rośliny Surinamu. Kunszt wykonania tych małych dzieł sztuki budzi podziw dla umiejętności artystycznych Merian.

Książka Natalie Zemon Davis to interesująca i pouczająca lektura, którą zamyka krótki podsumowujący rozdział. Jako doświadczona badaczka, Davis wyciąga pouczające wnioski ze swoich badań, ponownie uzasadniając wybór, którego dokonała. Trzy siedemnastowieczne życiorysy dostarczają nie tylko informacji o społeczeństwie, kulturze, zwyczajach w XVII wieku w Europie i obu Amerykach, czy nawet o bohaterkach wybranych, aby opowiedzieć ich życie; na kolejnym poziomie publikacja jest także informacją o tym jak należy prowadzić badania naukowe, w jaki sposób korzystać z tego, co kryje się w źródłach, a w szczególności jakie pytania należy źródłom stawiać, żeby możliwe było zrekonstruowanie za ich pomocą historii, którą opowiadają. 